\title{
Simultaneous Coexistence of Thyrotropin-Prolactin-Secreting Adenoma and Papillary Thyroid Carcinoma
}

\author{
Somaya Safi $\left(\mathbb{D},,^{1,2}\right.$ Yousra Benabdelfedil ${ }^{\circ},{ }^{1,2}$ Sara Derrou $\left(\mathbb{D},{ }^{1,2}\right.$ and \\ Faycal El Guendouz $\mathbb{D}^{1,2}$ \\ ${ }^{1}$ Department of Endocrinology, Moulay Ismail Military Hospital, Meknes, Morocco \\ ${ }^{2}$ Department of Fundamental Sciences, Laboratory of Human Pathology Biomedicine and Environment, \\ Faculty of Medicine and Pharmacy of Fez (FMPF), Sidi Mohammed Ben Abdellah University (USMBA), Fez, Morocco
}

Correspondence should be addressed to Faycal El Guendouz; el.guendouz@gmail.com

Received 5 May 2021; Accepted 11 November 2021; Published 30 November 2021

Academic Editor: Mihail A. Boyanov

Copyright (c) 2021 Somaya Safi et al. This is an open access article distributed under the Creative Commons Attribution License, which permits unrestricted use, distribution, and reproduction in any medium, provided the original work is properly cited.

Background. The thyrotropin-secreting adenomas are very rare and even more rare when they simultaneously coexist with thyroid carcinoma. So far, only sixteen cases have been reported in the literature. Here, we present a unique case of successful management of a concurrent case of thyrotropin-prolactinoma with papillary thyroid carcinoma. Case Presentation. A 50-year-old Moroccan woman underwent a total thyroidectomy and complementary totalization by iratherapy for papillary thyroid carcinoma, who presented persistence of an inappropriate secretion of the thyroid-stimulating hormone (TSH $>4 \mathrm{mUI} / \mathrm{L}$ ) despite of levothyroxine suppressive therapy $(300 \mu \mathrm{g} / \mathrm{d})$. After eliminating noncompliance, interfering medicines, and thyroid malabsorption, a pituitary adenoma (12 mm) was documented at magnetic resonance imaging. The patient has had transsphenoidal pituitary adenomectomy with histology confirming a thyrotropin-prolactin-secreting adenoma. After surgery and lanreotide treatment failures, we noted a complete response $(\mathrm{TSH}<0.5)$ with cabergoline treatment $(3 \mathrm{mg} /$ week $)$. Conclusion. The unusual association of thyroid adenocarcinoma and TSHoma enriches the hypothesis of a potential link between thyrotropic hypersecretion and thyroid carcinogenesis. Our case also illustrates the difficulty of monitoring thyroid carcinoma in nonremission of a TSHoma.

\section{Introduction}

The thyrotropin-secreting adenomas (TSHomas) are very rare; their prevalence accounts for $0.5-3 \%$ of all pituitary tumors [1]. The sensitive laboratory assays and the accuracy of magnetic resonance imaging currently allow early and precise diagnosis. Simultaneous coexistence of TSHoma and papillary thyroid carcinoma (PTC) is still exceptional, and so far, only sixteen cases have been reported [2-14]. This association suggests the involvement of TSH in thyroid carcinogenesis and raises the difficulty of monitoring levothyroxine suppressive therapy in thyroid carcinoma after a total thyroidectomy.

\section{Observation}

A 50-year-old Moroccan woman, followed for type 2 diabetes, who underwent a total thyroidectomy with histology confirming papillary thyroid carcinoma (measuring $10 \mathrm{~mm}$ ) classified T1b Nx M0 (Figure 1). She also received an adjuvant therapy with $100 \mathrm{mCi}$ of radioactive iodine. Posttherapy wholebody scanning revealed fixation in the right thyroid bed compatible with thyroid remnant without metastasis. Cervical ultrasound did not objectify any residue or lymphadenopathy. We noted persistently unrepressed TSH after gradual dose levothyroxine suppressive therapy up to $300 \mu \mathrm{g}$ per day $(4 \mu \mathrm{g} /$ $\mathrm{kg} /$ day); her serum TSH level fluctuating from 4.5 to $50 \mu \mathrm{IU} /$ $\mathrm{mL}$ and thyroglobulin (Tg) level was $6.8 \mathrm{ng} / \mathrm{mL}$. We had quickly eliminated noncompliance, interfering medicines, and thyroid malabsorption, and we suspected a syndrome of inappropriate TSH secretion (SITSH). A pituitary MRI showed a macroadenoma in the sella turcica $(10 \times 12 \mathrm{~mm})$, without local mass effect on adjacent structures, especially optic chiasm (Figure 2). The specific investigation was in favor of TSHoma, in particular the absence of TSH suppression in the T3 


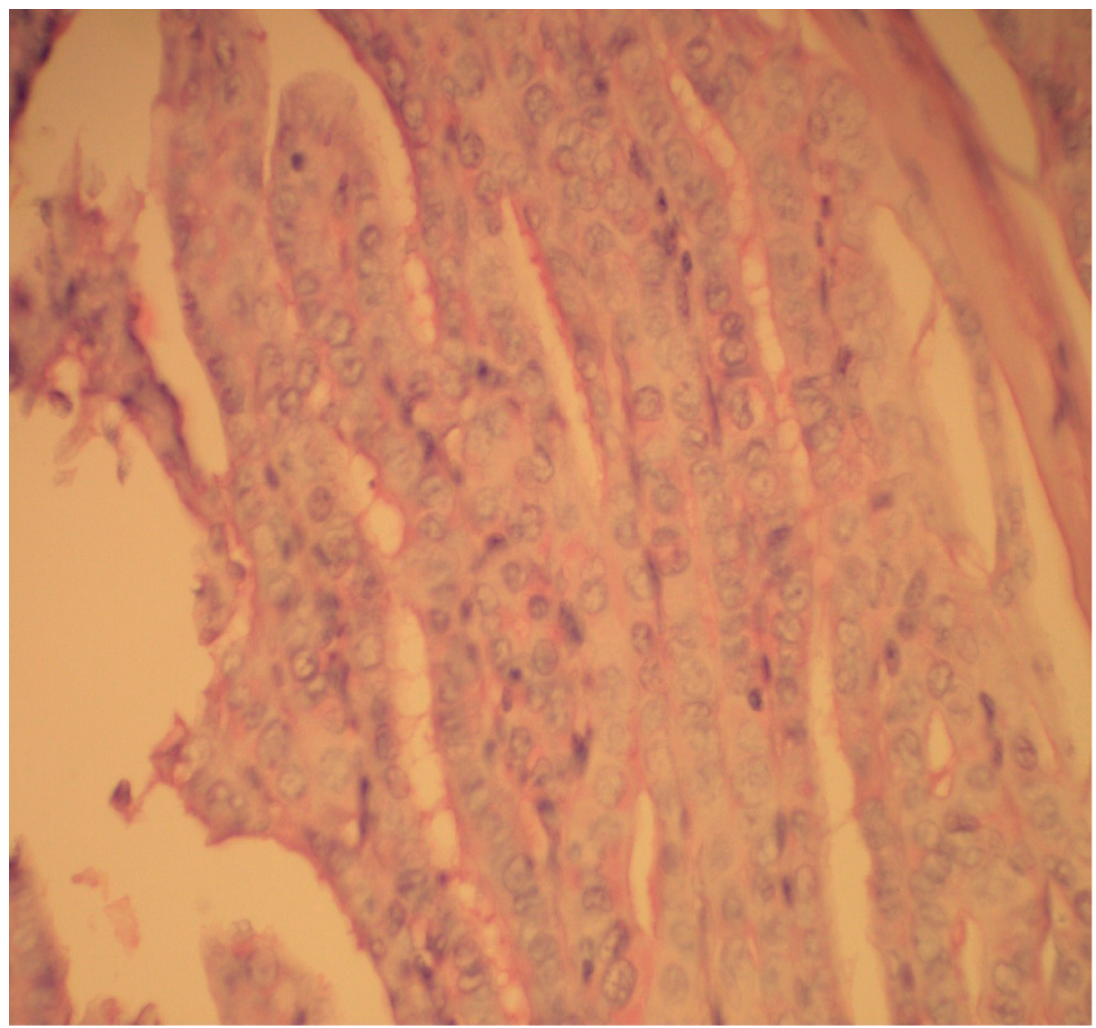

FIGURE 1: Nuclear features of papillary thyroid carcinoma, ground glass appearance, intranuclear grooves, nuclear crowding, and overlapping (x400).

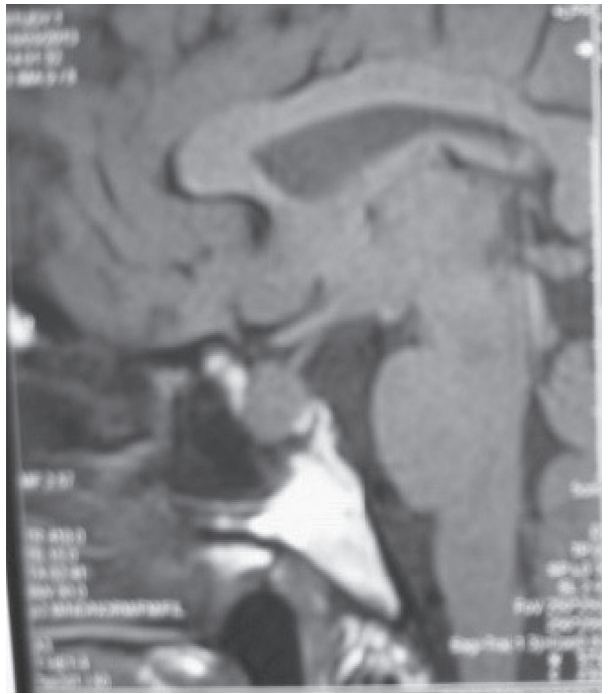

(a)

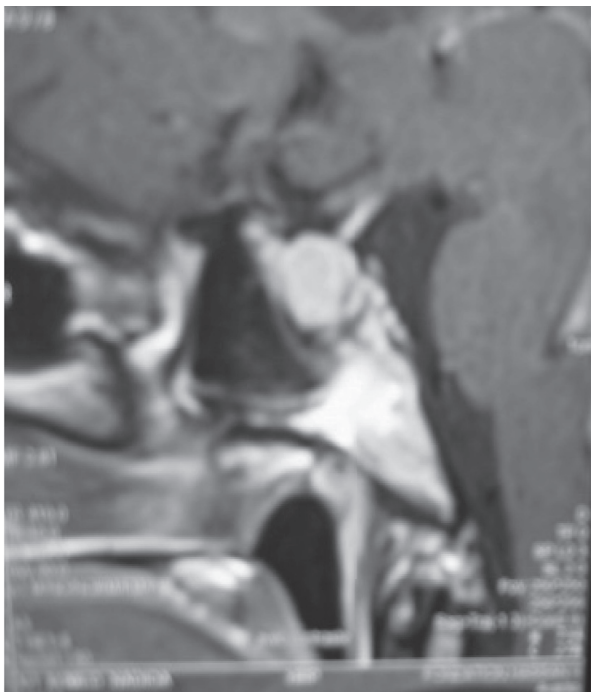

(b)

FIgURE 2: Preoperative pituitary MR images (T1-weighted, contrast, and sagittal view) showing (a) pituitary macroadenoma $12 \mathrm{~mm}$ without mass effect on adjacent structures (especially optic chiasm) and (b) strong homogeneous enhancement of the pituitary adenoma after contrast administration.

suppression test ( $100 \mu \mathrm{g} /$ day divided in 3 administrations), the serum alpha-subunit levels ( $\alpha$-GSU) was $4.9 \mathrm{ng} / \mathrm{mL}$ (normal postmenopausal value 0.6 to $1.5 \mathrm{ng} / \mathrm{mL}$ ), and $\alpha$-GSU/TSH molar ratio was 1.4 (normal $<1$ ). Other investigations to evaluate pituitary function were normal (Table 1).
Accordingly, the patient has had transsphenoidal pituitary adenomectomy with histology confirming a thyrotropin-prolactin-secreting adenoma $(50 \%$ of $\beta \mathrm{TSH}$ immunoreactivity and $25 \%$ of prolactin immunoreactivity) (Figure 3). 
Table 1: Pertinent laboratory findings.

\begin{tabular}{|c|c|c|c|c|c|c|}
\hline Investigations & Before admission & At admission & After surgery & After lanreotide & After cabergoline & Reference range \\
\hline $\mathrm{TSH}(\mu \mathrm{IU} / \mathrm{mL})$ & $4.5-50$ & 35 & 20 & 6 & 0.5 & $0.35-4.95$ \\
\hline FT4 (pmol/L) & - & 23 & 24 & 22 & 19 & $12-22$ \\
\hline FT3 (pmol/L) & - & 5.3 & 6.7 & 6.6 & 5.9 & $2.8-7.1$ \\
\hline Thyroglobulin (ng/mL) & - & 6.8 & 22.7 & 8 & 0.4 & $<1$ \\
\hline$\alpha$ subunit $(\mathrm{ng} / \mathrm{mL})$ & - & 4.9 & - & - & - & $0.6-1.5$ \\
\hline$\alpha$-GSU/TSH molar ratio & - & 1.4 & - & - & - & $<1$ \\
\hline LH (IU/L) & - & 36.8 & - & - & - & $2.4-12.6$ \\
\hline FSH (IU/L) & - & 84.1 & - & - & - & $3.5-12.5$ \\
\hline Estradiol (pmol/L) & - & 51 & - & - & - & $46-607$ \\
\hline Prolactin (mIU/L) & - & 250 & 230 & - & 90 & $72-511$ \\
\hline Cortisol (nmol/L) & - & 525 & - & - & - & $171-536$ \\
\hline ACTH $(\mathrm{pg} / \mathrm{mL})$ & - & 40 & - & - & - & $7-63$ \\
\hline IGF1 $(\mu \mathrm{g} / \mathrm{L})$ & - & 102 & - & - & - & $93-245$ \\
\hline
\end{tabular}

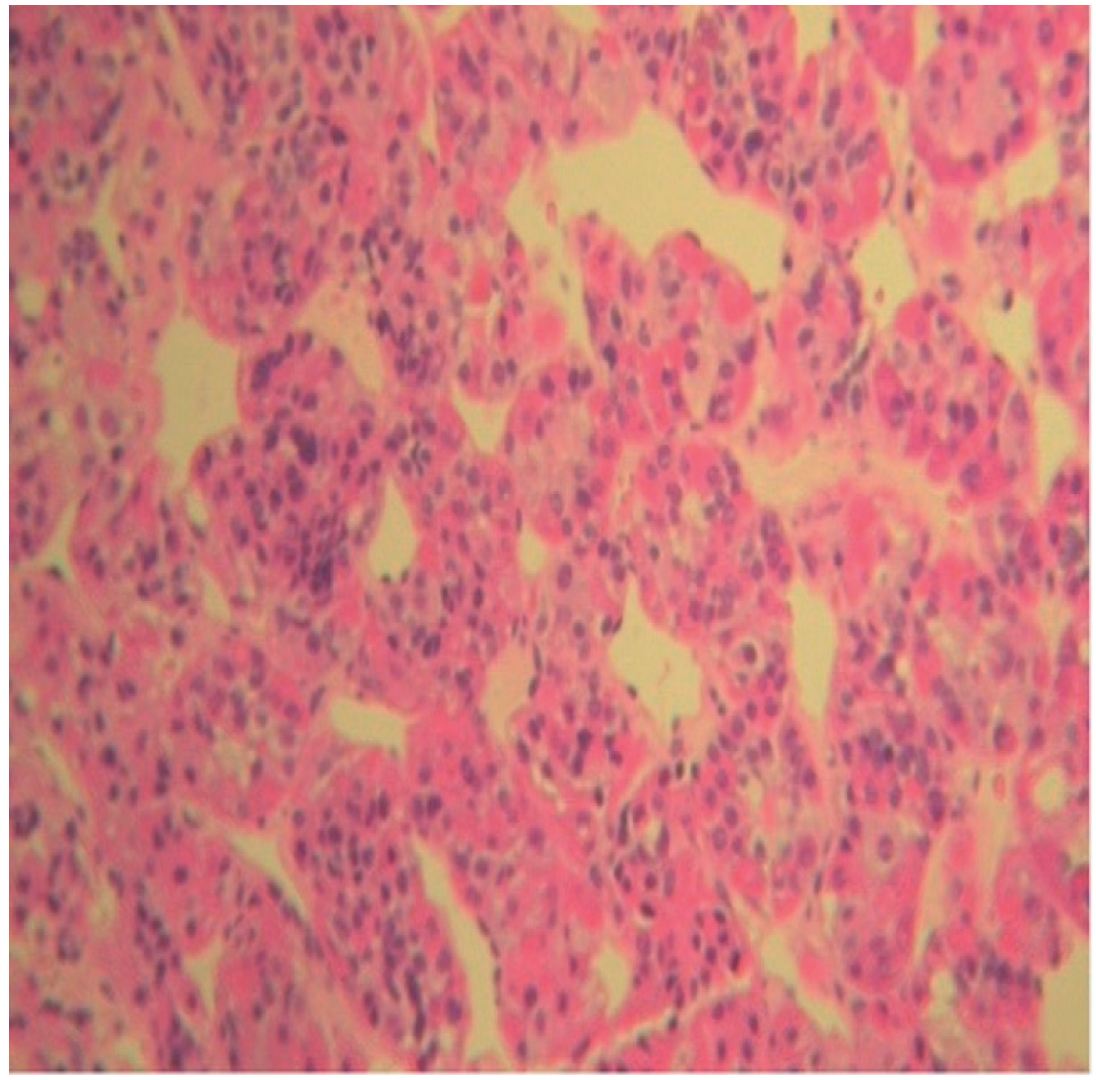

(a)

Figure 3: Continued. 


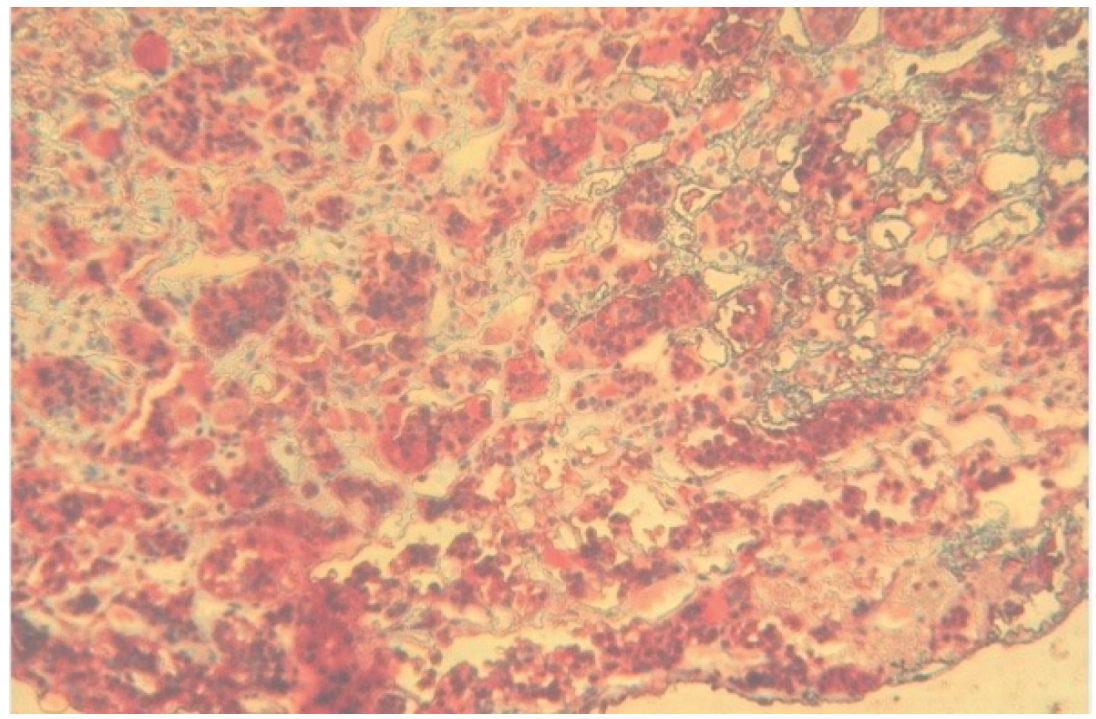

(b)

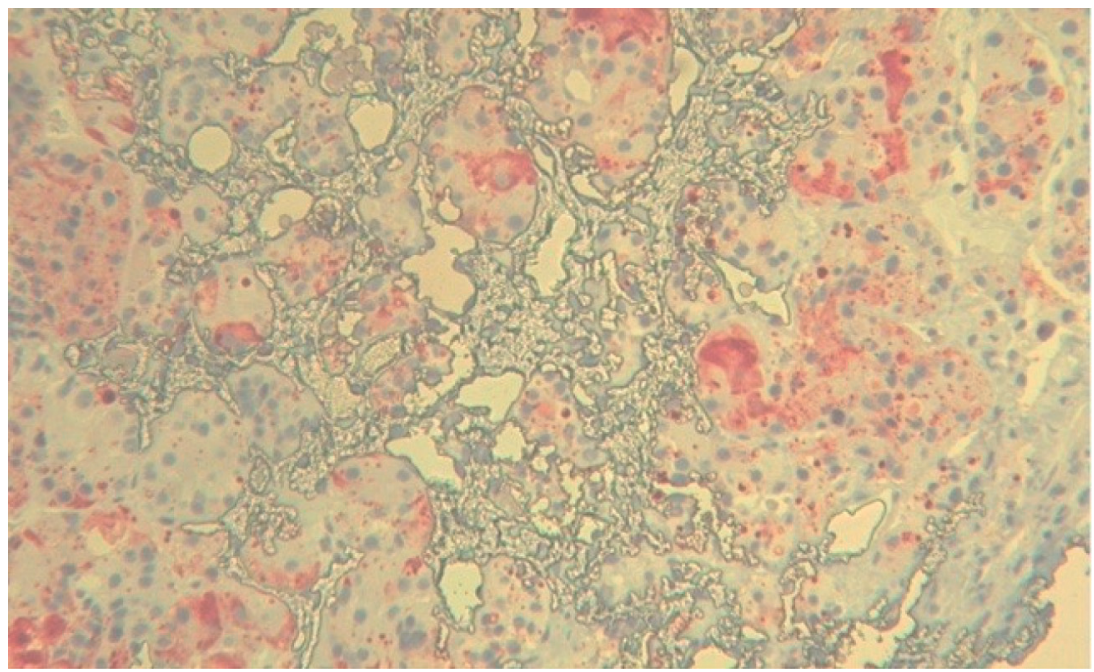

(c)

FIGURE 3: Histopathological and immunohistochemical study showing (a) histopathological features of pituitary adenoma (x200), (b) 50\% of $\mathrm{BTSH}$ immunoreactivity (x400), and (c) $25 \%$ of prolactin immunoreactivity (x400).

Three months after surgery, no residual tumor was apparent on pituitary MRI, but we noted a persistence of inappropriate secretion of TSH under $300 \mu \mathrm{g} / \mathrm{d}$ of levothyroxine, TSH level was $20 \mu \mathrm{IU} / \mathrm{mL}$, FT4 level was $22.4 \mathrm{pmol} / \mathrm{l}$, FT3 level was $5.6 \mathrm{pmol} / \mathrm{l}$, and $\mathrm{Tg}$ level was $22.7 \mathrm{ng} / \mathrm{mL}$ (Table 1). Given the absence of biological remission after surgery, the patient underwent lanreotide therapy at $90 \mathrm{mg}$ per month for three months, but the TSH level was still increased which provokes the stop of lanreotide. The TSH level was lowered for the first time after switching to cabergoline therapy and it allowed a complete response under $3 \mathrm{mg}$ per week (Table 1). The follow-up is eight years after cabergoline therapy with a good cardiac tolerance: the patient has managed to achieve complete remission of thyroid cancer without any biochemical or structural recurrence (low nonstimulated thyroglobulin levels, normal cervical ultrasound, and negative 131I-whole- body scan). Automatically levothyroxine dosage was gradually reduced to $125 \mu \mathrm{g} /$ day.

\section{Discussion}

We present here a case of thyroid cancer in coexistence with thyrotropin-prolactin-secreting adenoma. The sixteen published cases are reviewed and compared with our patient at the level of many parameters: age, sex, size of thyroid cancer, size of TSHoma, immunohistochemical study results, therapies used, and observed evolution (Table 2) [2-14].

TSH-suppressive hormonal therapy is a cornerstone of thyroid carcinoma therapy. Unrepressed TSH after levothyroxine suppressive therapy first evokes noncompliance, interfering medicines, thyroid malabsorption, and biological interference, before conducting further investigations for 
TABLE 2: Literature review of thyroid cancer with TSHoma.

\begin{tabular}{|c|c|c|c|c|c|c|c|c|c|c|}
\hline Case & Age & Sex & $\begin{array}{l}\text { Size of } \\
\text { TC } \\
(\mathrm{mm}) \\
\end{array}$ & $\begin{array}{l}\text { Size of } \\
\text { PA } \\
(\mathrm{mm})\end{array}$ & $\begin{array}{c}\text { IHC of } \\
\text { PA }\end{array}$ & Therapies of TSHoma & Therapies of TC & $\begin{array}{c}\text { Evolution of } \\
\text { TSHoma }\end{array}$ & $\begin{array}{l}\text { Evolution } \\
\text { of TC }\end{array}$ & $\begin{array}{c}\text { References } \\
\text { (year of } \\
\text { publication) }\end{array}$ \\
\hline 1 & 55 & M & 50 & 30 & TSH & TS adenomectomy & $\begin{array}{c}\text { Total } \\
\text { thyroidectomy/ } \\
\text { iratherapy }\end{array}$ & Remission & Remission & [2] (1991) \\
\hline 2 & 37 & $\mathrm{~F}$ & 20 & 10 & TSH & Refusing treatment & $\begin{array}{c}\text { Total } \\
\text { thyroidectomy/ } \\
\text { iratherapy }\end{array}$ & NR & Remission & [3] (1998) \\
\hline 3 & 27 & $\mathrm{~F}$ & 30 & 10 & TSH & $\begin{array}{l}\text { Octreotide/TS } \\
\text { adenomectomy }\end{array}$ & $\begin{array}{l}\text { Partial } \\
\text { thyroidectomy }\end{array}$ & Remission & NR & [4] (2000) \\
\hline 4 & 45 & $\mathrm{~F}$ & 20 & 15 & TSH & $\begin{array}{l}\text { Octreotide/TS } \\
\text { adenomectomy }\end{array}$ & $\begin{array}{l}\text { Total } \\
\text { thyroidectomy }\end{array}$ & Remission & NR & [5] $(2001)$ \\
\hline 5 & 47 & $\mathrm{~F}$ & 8 & 4 & $\begin{array}{l}\text { TSH/ } \\
\text { PRL }\end{array}$ & TS adenomectomy & $\begin{array}{c}\text { Total } \\
\text { thyroidectomy/ } \\
\text { iratherapy }\end{array}$ & NR & Remission & [6] (2006) \\
\hline 6 & 50 & $\mathrm{M}$ & 17 & 3 & TSH & Refusing treatment & $\begin{array}{c}\text { Total } \\
\text { thyroidectomy }\end{array}$ & Stability & Remission & [7] (2009) \\
\hline 7 & 57 & $\mathrm{~F}$ & 8 & 26 & $\begin{array}{c}\mathrm{TSH} / \\
\mathrm{GH}\end{array}$ & Octreotide & $\begin{array}{c}\text { Total } \\
\text { thyroidectomy/ } \\
\text { iratherapy }\end{array}$ & Remission & Remission & [8] (2010) \\
\hline 8 & 38 & $\mathrm{~F}$ & 40 & 14 & $\begin{array}{l}\text { TSH/ } \\
\text { FSH }\end{array}$ & $\begin{array}{l}\text { Octreotide/TS/ } \\
\text { radiosurgery }\end{array}$ & $\begin{array}{l}\text { Total } \\
\text { thyroidectomy/ } \\
\text { iratherapy }\end{array}$ & Stability & Remission & [9] (2013) \\
\hline 9 & 27 & $\mathrm{~F}$ & 10 & 28 & TSH & $\begin{array}{l}\text { TS adenomectomy/ } \\
\text { lanreotide }\end{array}$ & $\begin{array}{l}\text { Total } \\
\text { thyroidectomy/ } \\
\text { iratherapy }\end{array}$ & $\begin{array}{l}\text { Partial } \\
\text { response }\end{array}$ & Remission & [9] (2013) \\
\hline 10 & 33 & $\mathrm{~F}$ & 14 & 20 & $\begin{array}{c}\mathrm{TSH} / \\
\mathrm{GH}\end{array}$ & $\begin{array}{l}\text { TS adenomectomy/ } \\
\text { cabergoline }\end{array}$ & $\begin{array}{c}\text { Total } \\
\text { thyroidectomy/ } \\
\text { iratherapy }\end{array}$ & Remission & Remission & [10] (2014) \\
\hline 11 & 47 & $\mathrm{M}$ & 15 & 19 & TSH & $\begin{array}{l}\text { TS adenomectomy/ } \\
\text { lanreotide }\end{array}$ & $\begin{array}{c}\text { Total } \\
\text { thyroidectomy/ } \\
\text { iratherapy }\end{array}$ & Remission & Remission & [11] (2015) \\
\hline 12 & 46 & $\mathrm{M}$ & 12 & 7 & $\begin{array}{c}\mathrm{TSH} / \\
\mathrm{GH}\end{array}$ & $\begin{array}{l}\text { TS adenomectomy/ } \\
\text { lanreotide }\end{array}$ & $\begin{array}{l}\text { Total } \\
\text { thyroidectomy/ } \\
\text { iratherapy }\end{array}$ & Remission & Remission & [11] (2015) \\
\hline 13 & 42 & M & 40 & 12 & TSH & TS adenomectomy & $\begin{array}{l}\text { Total } \\
\text { thyroidectomy/ } \\
\text { iratherapy }\end{array}$ & Remission & Remission & [11] (2015) \\
\hline 14 & 44 & $\mathrm{~F}$ & 30 & 16 & $\begin{array}{l}\mathrm{TSH} / \\
\mathrm{GH} / \\
\mathrm{FSH}\end{array}$ & $\begin{array}{l}\text { Octreotide/TS } \\
\text { adenomectomy }\end{array}$ & $\begin{array}{c}\text { Total } \\
\text { thyroidectomy/ } \\
\text { iratherapy }\end{array}$ & Remission & Remission & [12] (2017) \\
\hline 15 & 27 & $\mathrm{~F}$ & NR & NR & TSH & $\begin{array}{l}\text { Surgical resection for } \\
\text { nasopharyngeal tumor } \\
\text { (ectopic TSHoma) }\end{array}$ & $\begin{array}{c}\text { Total } \\
\text { thyroidectomy/ } \\
\text { iratherapy }\end{array}$ & Remission & Remission & [13] (2017) \\
\hline 16 & 57 & M & NR & 30 & TSH & $\begin{array}{l}\text { Octreotide/TS } \\
\text { adenomectomy }\end{array}$ & $\begin{array}{c}\text { Partial } \\
\text { thyroidectomy }\end{array}$ & Remission & Remission & [14] (2018) \\
\hline $\begin{array}{l}\text { Our } \\
\text { case }\end{array}$ & 50 & $\mathrm{~F}$ & 10 & 12 & $\begin{array}{l}\text { TSH/ } \\
\text { PRL }\end{array}$ & $\begin{array}{l}\text { TS adenomectomy/ } \\
\text { lanreotide/cabergoline }\end{array}$ & $\begin{array}{c}\text { Total } \\
\text { thyroidectomy/ } \\
\text { iratherapy }\end{array}$ & Remission & Remission & $-(2021)$ \\
\hline
\end{tabular}

NR, not reported; TC, thyroid cancer; PA, pituitary adenoma; IHC, immunohistochemistry; TSH, thyrotropin; PRL, prolactin; GH, growth hormone; FSH, follicle-stimulating hormone; TS, transsphenoidal.

SITSH. These diagnoses can be easily excluded by questioning, monitoring of drug intake, testing malabsorption, and repeating serum TSH measurement with several laboratory methods to exclude transitory changes and biological interference $[15,16]$. Once these diagnoses are excluded, we are therefore faced with SITSH and the second step is to differentiate between TSHoma and syndromes of thyroid hormone resistance (RTH) [16, 17]. The differential diagnosis is complicated, so clinical presentations, laboratory assessment, and imaging advances may help and guide diagnosis (Table 3 ). T3 suppression test is the most specific and sensitive test, especially in patients with thyroid ablation. $\alpha$-GSU may also be used; an elevated $\alpha$-GSU concentration or a high $\alpha$-GSU/TSH molar ratio favors the diagnosis of TSHoma in particular, in macroadenoma; these parameters are within the normal range in the case of a 
TABLE 3: The differential diagnosis markers between TSH-secreting adenomas (TSHomas) and resistance to thyroid hormones (RTH).

\begin{tabular}{lcc}
\hline & TSHoma & RTH \\
\hline Family history of thyroid disease & Absent & $85 \%$ \\
Unsuppressed TSH or increased & Present & Present \\
Elevated thyroid hormone levels & Present & Present \\
Nycthemeral profile of TSH & Absent & Present \\
High levels of SHBG (TeBG) & Present & Absent \\
Increased $\alpha$ subunit & $65 \%$ & $3 \%$ \\
$\alpha$-GSU/TSH molar ratio & $>1 \%$ & $<1 \%$ \\
Increase in TSH after a TRH & Negative & Positive \\
T3 suppression test & No TSH suppression & Suppression of TSH \\
Somatostatin test & FT4 $\downarrow>30 \%$ & FT4 is not affected \\
Multihormonal production & Possible & Absent \\
MRI pituitary & $98 \%$ & $10-20 \%$ \\
DNA mutation analysis & - & + \\
\hline
\end{tabular}

microadenoma [18]. Due to their low sensitivity and high variability in several conditions such as age and menopause, $\alpha$-GSU and GSU/TSH molar ratio may rarely help in the differential diagnosis [19]. Other tests are useful in the differential diagnosis like the increase of liver parameter such as the sex hormone binding globulin (SHBG) in the case of TSHomas, while it is normal in RTH $[20,21]$ (Table 3). This test was not performed in our patient because she was under a supraphysiological dose of levothyroxine. In addition, a difficulty of imaging lies in the presence of pituitary incidentalomas in $10-20 \%$ of the normal population and they are more frequent than TSHoma, so autonomous TSH production must be established [22, 23]. Finally, an association between TSHoma and RTH has been reported, hence the interest in gathering clinical, hormonal, and morphologic information [24]. In our patient, the radiological findings (pituitary macroadenoma) were associated with clinical data (no family history of thyroid disease) and biological findings (unrepressed TSH in T3 suppression test and elevated $\alpha$-GSU level and $\alpha$-GSU/TSH molar ratio), which allowed diagnosis of TSHoma.

Many cases of TSHomas are completely asymptomatic which explains why the majority of TSHomas are macroadenomas as in our patient [20] Therefore, it is important that the clinician be alerted to persistently unrepressed TSH after levothyroxine suppressive therapy in order to be able to carry out investigations and treat TSHoma as early as possible. On the other hand, it is so difficult to control and to monitor the carcinologic side of PTC when it coexists simultaneously with TSHoma as in our case.

The unusual association of PTC with TSHomas enriches the hypothesis of a potential link between thyrotropic hypersecretion and thyroid carcinogenesis. Thus, the role of TSH in carcinogenesis and development of PTC have been suggested in several studies where we noted high incidence of PTC in the patients with TSHomas and a meta-analysis of 28 studies have objectified a significant association between TSH levels and the risk of PTC $[20,25,26]$. Conversely, thyroidectomy when performed first before resection of pituitary adenoma may affect growth rate and secretion of the TSHoma due to diminished negative feedback effect of thyroid hormones [9]. This is the same mechanism described in Nelson's syndrome after adrenalectomy in Cushing's disease.
There are several therapeutic modalities for TSHoma, but the first line therapy is transsphenoidal pituitary surgery in order to remove tumor mass and to normalize TSH, with a success rate of $80 \%[27,28]$. In our case, surgery allowed removing tumor mass without TSH suppression. Second-line treatments include repeat pituitary surgery, radiation therapy, and medical therapy; they should be considered after failed transsphenoidal surgery and when the patient is not amenable to surgery or he declines it. Radiotherapy (conventional fractional radiotherapy or radiosurgery) may also be indicated in the treatment of TSHoma; however, the benign character of the condition, the potential side effects of radiation in particular hypopituitarism, and the long delay between radiation and efficacy will make its use less frequent, especially when medical therapies provide good control of the disease as we will see below [29]. Somatostatin analogs (SA) are the best choice of medical alternative treatment; they restore normal thyroid function in about $95 \%$ and shrink the size of TSHoma in up to $50 \%$ of patients [30-32]. Resistance to SA in our case is most likely related to nonexpression of somatostatin receptors. The presence of dopamine receptors on the thyrotroph cells justifies the therapeutic use of dopaminergic agents in TSHomas; however, efficiency in control of TSH secretion and tumor shrinkage was lower compared to SA and the best results were obtained in mixed TSH/prolactin adenomas [30, 31, 33-36]. The immunohistochemical study had objectified an immunofixation for TSH and also for prolactin with the absence of clinical or biological symptoms of prolactinoma on admission (neither amenorrhea nor galactorrhea and normal serum prolactin); this situation defines the true silent prolactinoma. It is a rare entity, especially in macroprolactinoma, most frequently associated with somatotropic adenomas. Discovery of PRL positive staining may provide an option for dopamine agonists in the treatment of recurrent silent prolactinomas as illustrated in our observation [37].

\section{Conclusion}

The unusual association of PTC with TSHomas enriches the hypothesis of a potential link between thyrotropic hypersecretion and thyroid carcinogenesis. Our observation highlights efficiency of cabergoline in control of TSH secretion, especially in the presence of mixed TSH/ 
prolactin adenomas, without forgetting the difficulty encountered to control and to monitor the carcinologic side of PTC when it coexists simultaneously with TSHoma.

\section{Conflicts of Interest}

The authors declare that they have no conflicts of interest.

\section{References}

[1] P. Beck-Peccoz, L. Persani, and A. Lania, "Thyrotropin-Secreting Pituitary Adenomas," in Endotext, K. R. Feingold, B. Anawalt, A. Boyce et al., Eds., MDText.com, Inc., South Dartmouth, MA, USA, 2019.

[2] A. L. Calle-Pascual, E. Yuste, P. Martin et al., "Association of a thyrotropin-secreting pituitary adenoma and a thyroid follicular carcinoma," Journal of Endocrinological Investigation, vol. 14, no. 6, pp. 499-502, 1991.

[3] P. Gasparoni, D. Rubello, L. Persani, and P. Beck-Peccoz, "Unusual association between a thyrotropin-secreting pituitary adenoma and a papillary thyroid carcinoma," Thyroid, vol. 8, no. 2, pp. 181-183, 1998.

[4] M. Kishida, F. Otsuka, H. Kataoka et al., "Hyperthyroidism in a patient with TSH-producing pituitary adenoma coexisting with thyroid papillary adenocarcinoma," Endocrine Journal, vol. 47, no. 6, pp. 731-738, 2000.

[5] S. Ohta, S. Nishizawa, Y. Oki, and H. Namba, "Coexistence of thyrotropin-producing pituitary adenoma with papillary adenocarcinoma of the thyroid: a case report and surgical strategy," Pituitary, vol. 4, no. 4, pp. 271-274, 2001.

[6] A. Gessl, H. Vierhapper, and H. Feichtinger, "Non-suppressible TSH in a patient thyroidectomized due to follicular thyroid carcinoma," Experimental and Clinical Endocrinology \& Diabetes, vol. 114, no. 07, pp. 389-392, 2006.

[7] M. Poggi, S. Monti, C. Pascucci, and V. Toscano, "A rare case of follicular thyroid carcinoma in a patient with thyrotropinsecreting pituitary adenoma," The American Journal of the Medical Sciences, vol. 337, no. 6, pp. 462-465, 2009.

[8] H. D. Nguyen, M. S. Galitz, V. Q. Mai, P. W. Clyde, B. C. Glister, and M. K. M. Shakir, "Management of coexisting thyrotropin/growth-hormone-secreting pituitary adenoma and papillary thyroid carcinoma: a therapeutic challenge," Thyroid, vol. 20, no. 1, pp. 99-103, 2010.

[9] U. Ünlütürk, C. Sriphrapradang, M. F. Erdoğan et al., "Management of differentiated thyroid cancer in the presence of resistance to thyroid hormone and TSH-secreting adenomas: a report of four cases and review of the literature," Journal of Clinical Endocrinology \& Metabolism, vol. 98, pp. 2210-2217, 2013.

[10] B. Feigel-Guiller, "Association entre carcinome papillaire thyroïdien et adénome hypophysaire mixte thyréotrope et somatotrope, observation clinique et revue de la littérature," Université de Nantes, Nantes, France, Thèse de doctorat en médecine, 2014.

[11] F. Perticone, F. Pigliaru, S. Mariotti et al., "Is the incidence of differentiated thyroid cancer increased in patients with thyrotropin-secreting adenomas? Report of three cases from a large consecutive series," Thyroid, vol. 25, no. 4, pp. 417-424, 2015.

[12] P. Kiatpanabhikul, S. Shuangshoti, K. Chantra et al., "A case of coexistence of TSH/GH-secreting pituitary tumor and papillary thyroid carcinoma: challenges in pathogenesis and management," Journal of Clinical Neuroscience, vol. 41, pp. 78-80, 2017.

[13] J. Yang, S. Liu, Z. Yang, and Y. B. Shi, "Ectopic thyrotropin secreting pituitary adenoma concomitant with papillary thyroid carcinoma," Medicine, vol. 96, no. 50, Article ID e8912, 2017.

[14] H. Inoue, N. Shinojima, R. Ueda et al., "A rare case of thyrotropin-secreting pituitary adenoma coexisting with papillary thyroid carcinoma presenting with visual disturbance without hyperthyroidism," World Neurosurgery, vol. 119, pp. 394-399, 2018.

[15] O. Koulouri, C. Moran, D. Halsall, K. Chatterjee, and M. Gurnell, "Pitfalls in the measurement and interpretation of thyroid function tests," Best Practice \& Research Clinical Endocrinology \& Metabolism, vol. 27, no. 6, pp. 745-762, 2013.

[16] S. Laboureau-Soraes Barbosa, F. Boux de Casson, and V. Rohmer, "Exploration fonctionnelle de la thyroïde (en dehors de l'imagerie)," EMC-Endocrinologie-Nutrition, vol. 4, no. 4, pp. 1-11, 2007.

[17] P. Caron, "Adénomes hypophysaires à TSH ou adénomes thyréotropes," La Presse Médicale, vol. 38, no. 1, pp. 107-111, 2009.

[18] H. Socin, P. Chanson, B. Delemer et al., "The changing spectrum of TSH-secreting pituitary adenomas: diagnosis and management in 43 patients," European Journal of Endocrinology, vol. 148, no. 4, pp. 433-442, 2003.

[19] A. Tjörnstrand and H. F. Nyström, "Diagnosis OF endocrine disease: diagnostic approach to TSH-producing pituitary adenoma," European Journal of Endocrinology, vol. 177, pp. R183-R197, 2017.

[20] P. Beck-Peccoz, C. Giavoli, and A. Lania, “A 2019 update on TSH-secreting pituitary adenomas," Journal of Endocrinological Investigation, vol. 42, no. 12, pp. 1401-1406, 2019.

[21] P. Beck-Peccoz, A. Lania, A. Beckers, K. Chatterjee, and J.-L. Wemeau, "2013 European thyroid association guidelines for the diagnosis and treatment of thyrotropin-secreting pituitary tumors," European Thyroid Journal, vol. 2, no. 2, pp. 76-82, 2013.

[22] S. Ezzat, S. L. Asa, W. T. Couldwell et al., "The prevalence of pituitary adenomas," Cancer, vol. 101, no. 3, pp. 613-619, 2004.

[23] P. Beck-Peccoz, F. Brucker-Davis, L. Persani, R. C. Smallridge, and B. D. Weintraub, "Thyrotropin-secreting pituitary tumors*," Endocrine Reviews, vol. 17, no. 6, pp. 610-638, 1996.

[24] J. D. Safer, S. D. Colan, L. M. Fraser, and F. E. Wondisford, "A pituitary tumor in a patient with thyroid hormone resistance: a diagnostic dilemma," Thyroid, vol. 11, no. 3, pp. 281-291, 2001.

[25] A. Dorange, S. Triau, S. Mucci-Hennekinne et al., "An elevated level of TSH might be predictive of differentiated thyroid cancer," Annales d'Endocrinologie, vol. 72, no. 6, pp. 513-521, 2011.

[26] H. K. Kim, J. H. Yoon, S. J. Kim, J. S. Cho, S.-S. Kweon, and H.-C. Kang, "Higher TSH level is a risk factor for differentiated thyroid cancer," Clinical Endocrinology, vol. 78, no. 3, pp. 472-477, 2013.

[27] D. S. A. McLeod, K. F. Watters, A. D. Carpenter, P. W. Ladenson, D. S. Cooper, and E. L. Ding, "Thyrotropin and thyroid cancer diagnosis: a systematic review and doseresponse meta-analysis," Journal of Clinical Endocrinology \& Metabolism, vol. 97, no. 8, pp. 2682-2692, 2012.

[28] P. Beck-Peccoz, L. Persani, D. Mannavola, and I. Campi, “TSH-secreting adenomas," Best Practice \& Research Clinical 
Endocrinology \& Metabolism, vol. 23, no. 5, pp. 597-606, 2009.

[29] E. Malchiodi, E. Profka, E. Ferrante et al., "Thyrotropin-secreting pituitary adenomas: outcome of pituitary surgery and irradiation," Journal of Clinical Endocrinology \& Metabolism, vol. 99, no. 6, pp. 2069-2076, 2014.

[30] F. G. Amlashi and N. A. Tritos, "Thyrotropin-secreting pituitary adenomas: epidemiology, diagnosis, and management," Endocrine, vol. 52, no. 3, pp. 427-440, 2016.

[31] P. Chanson, J. Orgiazzi, P. J. Derome et al., "Paradoxical response of thyrotropin to L-dopa and presence of dopaminergic receptors in a thyrotropin secreting pituitary adenoma," Journal of Clinical Endocrinology \& Metabolism, vol. 59, no. 3, pp. 542-546, 1984.

[32] W. Zgliczynski, P. Zdunowski, I. Czajka-Oraniec, W. Jeske, and G. Zielinski, "The role of somatostatin analogues in treatment of TSH secreting pituitary adenomas," Thyroid Research, vol. 6, no. Supp 2, p. A64, 2013.

[33] Y.-H. Kao, T.-J. Chang, and T.-S. Huang, "Thyrotropin-secreting pituitary tumor presenting with congestive heart failure and good response to dopaminergic agonist cabergoline," Journal of the Formosan Medical Association, vol. 112, no. 11, pp. 721-724, 2013.

[34] T. Kienitz, M. Quinkler, C. J. Strasburger, and M. Ventz, "Long-term management in five cases of TSH-secreting pituitary adenomas: a single center study and review of the literature," European Journal of Endocrinology, vol. 157, no. 1, pp. 39-46, 2007.

[35] F. Mouton, F. Faivre-Defrance, C. Cortet-Rudelli et al., "TSHsecreting adenoma improved with cabergoline," Annales d'Endocrinologie, vol. 69, no. 3, pp. 244-248, 2008.

[36] J. Mulinda, S. Hasinski, and L. I. Rose, "Successful therapy for a mixed thyrotropin- and prolactin-secreting pituitary macroadenoma with cabergoline," Endocrine Practice, vol. 5, no. 2, pp. 76-79, 1999.

[37] J. Drummond, F. Roncaroli, A. B. Grossman, and M. Korbonits, "Clinical and pathological aspects of silent pituitary adenomas," Journal of Clinical Endocrinology \& Metabolism, vol. 104, no. 7, pp. 2473-2489, 2019. 